\title{
Adult Learner Multilingualism and Contributing and Hindering Factors in Acquiring Languages
}

\author{
Rahmawati Aprilanita ${ }^{1, *}$ \\ ${ }^{1}$ Universitas Negeri Malang, Indonesia \\ *Correspondence: Universitas Negeri Malang, Indonesia. E-mail: aalchakim@gmail.com
}

Received: December 27, $2017 \quad$ Accepted: January 11, $2018 \quad$ Online Published: January 15, 2018

doi:10.5430/ijelt.v5n1p29

URL: https://doi.org/10.5430/ijelt.v5n1p29

\begin{abstract}
This study focuses on multilingualism of adult learner who is learning English and Indonesia in Indonesia which English as its foreign language. The aim was to explore the factors that enables him to acquire languages in certain context or social environment. An adult male student (29 years old) from Comoro, South Africa was chosen for the subject of the study. Experiences from the subject as the participant of the research are discussed, drawing on critical theory to understand emerging phenomena such as plasticity, Krashen's five second language acquisition hypothesis and linguistics. The paper findings conclude that several factors such as motivations, plasticity, input, first language, agency, and age have been contributed most to the development of languages acquisition of the subject.
\end{abstract}

Keywords: multilingualism, plasticity, adult language learner, input

\section{Introduction}

Many theories have tried to explain how human learn, acquire and produce the language. Those theories are mixed in psycholinguistics which concerns about how human learn, acquire and produce language. In doing so, psycholinguistics needs to involve other disciplines like anthropology to trace the history of the first time human communicate to each other and also see the skulls of early humans as well as the comparison with the apes, the neuroscience to know how the brain works when processing or producing language, second language acquisition theory to know the factors: internal and external factors that influence the language acquisition, and linguistics as a system of language that provide theory of standard language. Human with remarkable language features (brain and linguistics oral production) make them possible to produce more than one languages or widely known as multilingualism. Brain with its plasticity or the ability to change and grow for the neuro system and structures as long as it is trained regardless the age. In our case, Ahmed Djumoi, 29 years old, male graduate students from Comoro, South Africa is multilingual person. He speaks Comoro, French, Arabic, and English while now he is living in Indonesia to pursue his masterdegree in English Language Teaching since January, 2017 at Universitas Negeri Malang, Indonesia. Our study aims to explain how this adult multilingual acquire Indonesian language and pursue his masterdegree of English Language teaching from non-native country.

\section{Related Researches}

Izadi (2013) conducted study on the possible sources available for Iranian EFL students. He conducted the study by using questionnaire and semi-structured interview. The findings described that Adult Iranian EFL students rely on very few sources outside of classroom setting such as English films, English story books or magazines, and some internet websites and some cases older siblings, group work can be the helpful sources to learn English for all four language skills.

Another study about cognitive approaches to third language acquisition by Mayo (2012) revealed that language acquisition is a complex multi-faceted process. The first strand is psychological strands sees the third language acquisition from cross-linguistic influence (CLI) which are language distance (typlogical distance between language define and identify between language and language families) and metalinguistic awareness (the learner ability to 
reflect language of the bilingual mind as factors that contribute to facilitate the L3 acquisition) as the two influencing factors with the focus on lexical level. The generative strand as the theory of universal grammar that claims language acquisition is biologically determined process constrained by a number of universal principles and language-specific functional and lexical categories. Third language acquisition is actually accumulation of prior languages.

Neuroscience has provided a profound explanation on how brain works on multilingual brain. The recent study by Weeks, Lam, Abutelabi, and Kong (2012) on executive and language control in the multilingual brain by using neuroimaging of a multilingual person (Cantonese as L1, English as L2, and Mandarin as L3) the subject of the study is a 77 years old with left frontal lobe and in the left temporo-parietal areas injured resulting in fluent aphasia. The result of the study revealed that the aphasia of multilingual caused unwanted language switching from L3 to L1 during the confrontation naming and discourse production task. It is related to the age of acquisition or the language dominance of Cantonese as the L3. Weeks, Lam, Abutelabi, and Kong (2012) contented that language control and domain-general executive control are served by a partially overlapping cognitive and neural system. Our case suggests that voluntary control of spoken word production in trilingual speakers shares neural substrata in the fronto basal ganglia system with domain-general executive control mechanisms. One prediction is that lesions to such a system would give rise to both pathological switching and impairments of executive functions in trilingual speakers.

Another neuroscience study on speech of adult bilinguals in 2011 was conducted by Ackermann, Winkler, Grodd, Nardo, Rota, Erb, Hu, and Reiterer. The study showed that significant individual differences as to how they employed their left-hemisphere speech areas: Higher hemodynamic activation in a distinct fronto- parietal network accompanied low ability, while high ability paralleled enhanced gray matter volume in these areas con-comitant with decreased hemodynamic responses. Finally and unexpectedly, males were found to be more talented foreign speech mimics. At the neuro-functional level (fMRI), we observed a clear-cut difference between low and high ability speakers as a function of their imitation ability: low ability imitators showed significantly higher amounts of activation and more extended clusters during sentence and word imitation.

A recent study on multilingual society was conducted in Lithuania by Extra and Ramoniene (2011) with Lithuanian, Russian, English and Polish, and German as their language. The language varieties belongs to the different proportion of ethnic groups in three cities in Lithuania. The similar highest frequencies reported language of schooling are Lithuanian and English co-occur. The pupils have access to English to a variety of media and English is commonly taught at school. The data showed that other languages are used as alternatives depending on the factors such as type of context and interlocutor. The use of other languages at home does not take place as the competition of the mainstream, language. The parents in another language also dominant in the mainstream language.

\section{Methodology}

This study employs participatory action research as the starting point with dialogue approach to get the deeper understanding of multilingualism phenomena as the participant, Djuomi, could cultivate being a multilingual person. He told story of how he learned several languages as a reflective method and we observed his daily life as the way to look deeper into the case of multilingualism. In doing so, we gave several questions to the subject as follows:

1. How many languages can you speak? What are they?

2. Which one is your first language?

3. In Comoro, what language do you use most?

4. How did you learn those languages?

5. How long did you learn those languages?

6. What are difficulties in learning those languages?

7. How do you learn English in Indonesia?

8. How do learn Indonesian language?

9. What language do you feel fit most? Why?

10. Why do you learn many languages?

11. In what age did you learn each of the languages (French, Arabic, and English)?

12. How do you get the feedback of those languages?

13. Which one are you learning better from the class or from friends, video, audio, etc (informal setting)? 


\section{Finding and Discussion}

The result of interview revealed that the subject, Ahmed Djumoi (29), studied many languages at school such as English and French since Junior High School, Arabic in elementary school as they have to study Al Qur'an, the Holy Scripture of Islam. Comoro's language is the L1, Arabic and French are L2 and English is L3 or foreign language. They learn Arabic since Comoro is an Islamic Country. French becomes second language like Arabic because historically, they were colonized by French. He started learning English when he was 19 years old as he said, "I learnt English when I was 19 years old". English is beneficial to get reputable job such as administration in government. There are many American school there, such as Star English, American Conner, IMT, etc. The difficulties that the subject must encounter in learning those languages is the negative interference of mother tongue. He has difficulties in pronunciation, writing, grammar, listening and practice and he was absent from all when he was at school age. The school as the formal setting is very beneficial and helpful in learning English than the informal setting since not many people in Comoro know or communicate in English.

Pursuing master degree in ELT in Indonesia which is not the native language country, forces him to learn other language again, Indonesia. During his stay in Indonesia, he lives in boarding house with 29 males. He tried to communicate in English and Indonesia with his friends. He also enrich himself for English sources by visiting websites. Djumoi's story of being multilingualism can be explained by many theories, researches, and science such as the neuro cognitive science and language acquisition theory as psycholinguistics also need those theories to explain how human process and produce language. The factors that enable Djumoi can be classified into the age, brain's plasticity, motivation and input.

\subsection{Adult Multilingual, Plasticity and Age}

Djumoi phenomena of being multilingual is possible because of the plasticity of the brain. There are many hypothesis related to the brain and the age of learning. One of the famous hypothesis in language learning is Krashen's critical period hypothesis. Krashen (2002) cited the work of Lenneberg (1967) who hypothesized that the development of cerebral dominance was complete around puberty or firmly established. This left hemisphere of the brain has reached the limit to language ability to transfer at puberty. Therefore, the foreign language foreign language accent cannot acquire easily after puberty as well as the automatic acquisition ability from exposure only seems also disappear. Lenneberg's critical period hypothesis refers to the period of time (age before puberty) which plasticity of the brain decreases with age both in neural, connections and lateralization in the area of phonology (Randal, 2007). Hence, we can see that Lenneberg suggests the native like pronunciation can only be acquired by learning foreign language at the age before puberty. Somehow, a number of studies have indicated that late bilinguals are much more likely to retain a foreign accent than early bilinguals (Randall, 2007).

Djumoi started learning English when he was 19 year old which means he reached his puberty when he started to learn English. Learning English also learn new vocabulary and grammar. He has limited grammatical competence but his pronunciation is native like. This phenomena can be explained by the current investigations have paid attention to how late and early bilingual used the left and right brain differently in processing languages. Mick Randall (2007) cited the work of Fabro (2001) who suggests that there is evidence that the brain imaging have the similar cerebral representation of lexicon between early and late bilingual but different in using declarative memory in which late bilingual used more than early bilinguals. Moreover, study by Whitaker (1978) and Paradis (1977) a cited by Randall (2007) show that a number of polyglot aphasic 23\% showed different impairment and recovery, over half showed no difference both languages were equally impaired or recovered at equal rates. The above findings suggest that ages do not influence the brain in learning language. Brain keeps changing and growing connection as shown by the recovery of aphasia. Randal (2007) cited from Ojeman and Whitaker (1978) another finding that the areas of the brain involved in the first and second languages are largely the same.

\subsection{Motivation and Agency as Contributing Factor in Learning Many Languages}

Kumaravaradivelu (2006) has classified motivation into one of affective factors which he refers to Routledge Encyclopedia, 2000, p.425 as "the driving force to sustain the long and often tedious learning process." Hence, the driven force that makes the subject and people in Comoro to learn many languages is based on the education system there. According to Krashen (2002) affective filter may delimit or filter the input such as motivations and attitude are not optimal. The affective filters are prior to linguistics consideration so if the affective filter is "up" no matter how meaningful and communicative input sequence is there will be little or no acquisition occur. The relationship between the affective factors and language acquisition can be seen below: 


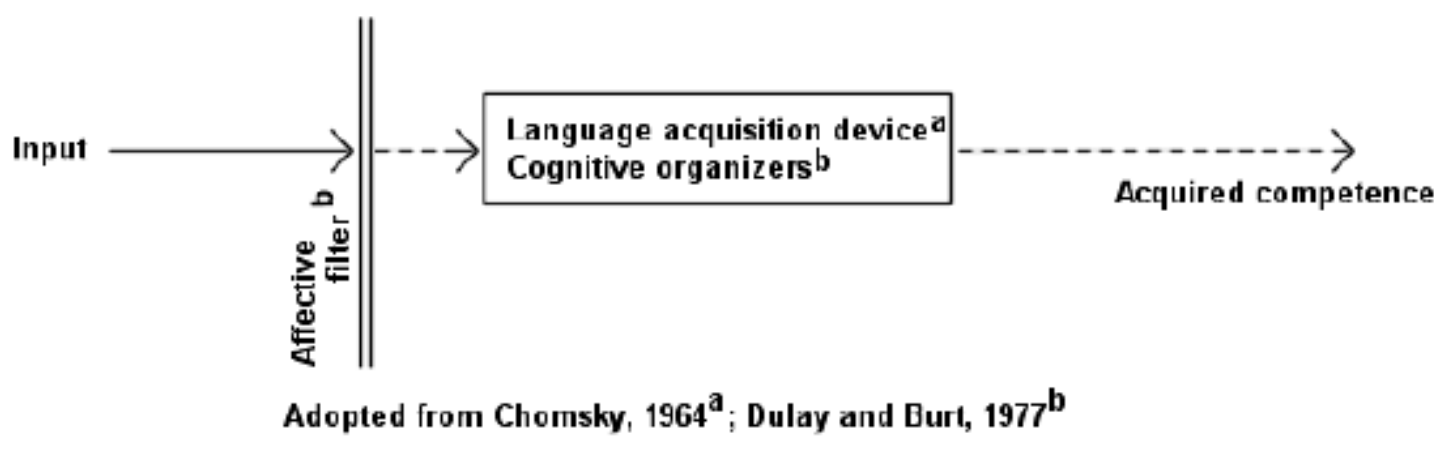

Figure 1. The Relationship between Affective Factors and Language Acquisition

Motivation does not solely comes from the individual desire but it is socially distributed and created within cultural system (Rueda \& Moll, 1994) as Comoro government through ministry of education obliges all people to learn Arabic, French and English from elementary school until high school. It is based on Djumoi explanation on why he had to learn many languages:

"I started learn many Languages because French, English and Arabic those the part of the material that we studied in the classroom in all the school.it the program of study of the ministry of education. I learnt Arabic when I was yang because Arabic is compulsory of all children to attend 5 years in coranic school.and French when I start to go to school, because we use French language in the beginning of study in the school. Also English when I arrived on the secondary school."

Moreover if they master English, they will get reputable job position in government administration. According to social psychologist Gardner and Lambert (1972) there are two kinds of motivation: the integrative and instrumental motivation. Someone learn language to integrate sociocultural to become a member of society of the targeted language. Meanwhile what is meant by instrumental motivation is when someone want to acquire something for functional purposes based on the learner's interest such as learning in the target language, getting a job, marrying someone, etc such as Djumoi's motivation to learn English and other languages are "I can improve my English everywhere in Comoros because they now it becomes international in the world. We will be respected of the Languages that you have behind French. Respected in the Administrator, in the society, and your personality." Hence, Gardner and McIntyre (1991) both of those motivations have consistent and meaningful effects on learning and behavioral changes.

The motivation that the subject have to learn many languages enable him to take further action intentionally for his future such as now he has been continuing his master degree of English language teaching in Indonesia. The ability to take action intentionally according to Brown (2015) is called agency. Hence the motivation leads the learner to take further action which can be explained by cognitive neuroscience (Damasio, 2003: Immordino Yang \& Damasio, 2007; Ryan 2007) how the emotion (motivation) plays fundamental role in reasoning and decision making based on the result of functional Magnetic Resonance Imaging (fMRI).

"It compulsory learning Arabic in Comoros because first the country is Islam country we use all the law and the role of the government. And French because we use the system Education of French we were colonies by French and also English it is material integrated by the ministry of education to be learn English but this language it up to you to learn English. We use only French and Arabic in the Administration because we considered the two Languages as official language in all Administrator."

Related to motivation which is seen as part of emotion is intricately related to agency and decision making in language use and learning and how motivation, agency and decision making manifest their relationship to the real world to sociopolitical context (Brown, 2015). Djumoi as a part of people Comoro must obey the Government in all aspects including in Education. Comoro Government obligates its people to learn French as they see back to history in which French colonized them in the past it meets with what Norton (2000) proposed the idea of "the socially and historically constructed relationship of the learners to the target language, and their often ambivalent desire to learn and practice it." They see French politically higher from them. They might also feel the close relationship from the history so even when now they are not colonized anymore but they have already seen French as above them, so they still maintain the relationship by using the language and pass them down to the next generation through education 
system. Meanwhile, learning English for Djumoi uttered that "I can improve my English every where in Comoros because they now it becomes international in the world. We will be respected of the Languages that you have behind French. Respected in the Administrator,in the society,and your personality." Hence we can see that Djumoi is aware his relation to the world and his future as Norton (2000) argues that, "how a person understands his or her relationship to the world, how that relationship is constructed across time and space, and how the person understands possibilities for the future."

\subsection{Role of Environment as Available Input}

Djumoi has been learning English since he was 19 from school. He did not get exposure outside of the school because not many Comoro people know English. English is foreign language and this became his difficulty in learning English. In this case, he got input merely from class which was the formal setting. According to Krashen (2002) there are two linguistics environment that serve as input for language learning: artificial or formal environment which are found in the classroom, and natural or informal environments. Krashen and Seliger (1975) found that all those language teaching systems utilized for the adult use activities with linguistic rules and feedback given.

Several studies that have been observed by Krashen (2002) found that formal setting enabled adult to learn better than in informal setting or situations. Krashen (2002), "Finally, there is the well-established fact from child language acquisition studies that comprehension normally precedes production." According to Djumoi, even though nowadays the advance information technology has enabled him to access informal input or many exposure but he found that the formal setting helped him better in improving his English as he states that "In my country the formal approach of learning English exposure and help my proficiency than the informal approach, because English is not our official language in my country but French, so in the classroom it is far better than learning outside the classroom as many people only knew how to speak and write French."

\subsection{The Role of the First Language in Second Language Acquisition}

One of the interference that Djumoi must encounter in learning English is the mother language or Comorian language. Its differences in the level of morphology, phonology and syntax has hindered him in learning English besides the absent of informal input of English as he explained below:

"The difficult that I got to learn those languages it so many because learning a language of the negative interference of the mother tongue. So learn Language we have some references of the mother tongue. and all those are foreign, I want to say I could apply knowledge from the native language. Many difficult such as the prononciation, writing, grammar, and listening and practice because learning a language need to complete all those elements to success for the language. All that it was absent from me to learn those languages."

Krashen (2002) has explained the role of first language in second language acquisition as followed:

1. First language influence appears to be strongest in complex word order and in word for- word translations of phrases.

2. First language influence is weaker in bound morphology.

3. First language influence seems to be strongest in "acquisition poor" environments.

Again Krashen (2002) put emphasis on the role of informal setting in providing better input for adult language learner in which he asserts that "it is interesting to note that we can find signs of first language influence in immersion bilingual programs where input is often primarily from the teacher and not from peers."

As Djumoi explained before that class instruction as formal input served better in improving his English. He also found the same when now he is pursuing master degree in Indonesia for English language teaching, he always got feedback from lecturers on his pronunciation or grammatical mistakes and he found them as more effective in improving his English.

"Now there is a group American who help to learn English there and they are also open many English school' such as American corner, Star English, IMT, etc. I can improve my English everywhere in Comoros because they now it becomes international in the world. We will be respected of the Languages that you have behind French. It easy for reading a lot extensive now we develop with a group Media ALBALAD of English and all Languages inside of Comoros." 


\section{Concluding Remarks}

Djumoi phenomena of being multilingual is possible because of the plasticity of the brain. The native like pronunciation can only be acquired by learning foreign language at the age before puberty. Somehow, a number of studies have indicated that late bilinguals are much more likely to retain a foreign accent than early bilinguals. The areas of the brain involved in the first and second languages are largely the same. The driven force that makes the subject and people in Comoro to learn many languages is based on the education system there. Motivation does not solely comes from the individual desire but it is socially distributed and created within cultural system. The motivation that the subject have to learn many languages enable him to take further action intentionally for his future such as now he has been continuing his master degree of English language teaching in Indonesia. Djumoi as a part of people Comoro must obey the Government in all aspects including in Education. Comoro Government obligates its people to learn French as they see back to history in which French colonized them in the past. In learning, one of the interference that Djumoi must encounter in learning English is the mother language or Comorian language. Its differences in the level of morphology, phonology and syntax has hindered him in learning English besides the absent of informal input of English Djumoi as adult learners found that the formal setting helped him better in improving his English despite of ample sources from internet. Therefore, the method of classroom for adult multilingual students should be optimized as the formal setting was found as better than informal setting in improving the English skills.

\section{References}

Brown, D., \& Lee, H. (2015). Teaching by Principles (4 ${ }^{\text {th }}$ Eds.) USA: Pearson Education, Inc.

García-Mayo, M. (2012). Cognitive Approaches To L3 Acquisition Retrieved on March 26 ${ }^{\text {th }}$, 2017 from www.um.es/ijes

Gardner, R.C., \& Lambert, W. E. (1972). Attitude \& Motivation in Second Language Learning. Rowley, M.A.: Newbury House.

Gardner, R.C., \& Maclntyre, P.D. (1991). An Instrumental Motivation in Language Study: Who Say IT Isn't Effective? Studies in Second Language Acquisition, 13(1), 57-72. https://doi.org/10.1017/S0272263100009724

Kong, A. P., Abutalebi, J., Lam, K. S., \& Weekes, B. 2014. Clinical Study Executive and Language Control in the Multilingual Brai. http://dx.doi.org/10.1155/2014/527951

Krashen, Stephen. (2002). Second Language Acquisition and Second Language Learning. California: Pergamont Pres Inc.

Kumaravaradivelu, B. (2006). Understanding Language Teaching: From Method to Post Method. London: Lawrence Erlbaum Associates Publishers.

Maria, R. S., Hu. X., Erb, M., Rota, G., Nardo, D., Grodd, W., Winkler, S., \& Ackermann, H. (2011). Individual differences in audio-vocal speech imitation aptitude in late bilinguals: functional neuro-imaging and brain morphology. $\quad$ Retrieved on March $26^{\text {th }}$, 2017 from http://journal.frontiersin.org/article/10.3389/fpsyg.2011.00271/full

Norton, B. (2000). Identity and language learning: Gender, ethnicity and educational change. London, UK: Pearson/Longman.

Randal, Mick. (2007). Memory, Psychology and Second Language Learning. Philadelphia: John Benjamin Publishing Company. https://doi.org/10.1075/11lt.19

Rueda, R., \& Moll, L.C. (1994). A Sociocultural Perspective on Motivation. In H. F O’Neil, Jr. \& M. Drillings (Eds.), Motivation: Theory \& Research (pp.117-137).

Ramonienè, M., \& Extra, G. (2011). Multilingualism in Lithuanian cities: aims and outcomes of a home language survey in Vilnius, Kaunas and Klaipeda Retrieved on March 26 $6^{\text {th }} 2017$ from https://doaj.org/article/3f0989cb7e774eab99a93ab153570a50

Kazemi, Ali. (2013). Social Context and Resources Available to Iranian Foreign Language Learners of English. International Journal of Applied Linguistics \& English Literature, 2(4), 127. http://dx.doi.org/10.7575/aiac.ijalel.v.2n.4p.127 